Jurnal Indonesia Sosial Teknologi: p-ISSN: 2723 - 6609

e-ISSN : 2745-5254

Vol. 2, No. 2 Februari 2021

\title{
PENANGANAN TINDAK PIDANA PEMILU DALAM SENTRA PENEGAKKAN HUKUM TERPADU (GAKKUMDU)
}

\author{
Sarah Bambang, Sri Setyadji dan Aref Darmawan \\ Universitas 17 Agustus 1945 Surabaya \\ Email: sarahbambang323@gmail.com, ebes.sriadji@gmail.com \\ arefdarmawan@untag.ac.id
}

\begin{abstract}
Abstrak
Latar Belakang Penelitian ini membahas tentang Penanganan Tindak pidana Pemilihan Umum melalui Sentra Peneggakan Hukum terpadu oleh Badan Pengawas Pemilihan Umum Namun dalam proses Peneggakkanya adanya perbedaan pendapat dalam menangani permasalah pada tindak pidana Pemilu tersebut,maka perlu adanya Penyamaan Persepsi terkait karakteristik Tindak Pidana Pemilihan Umum dan Kewenangan Sentra Gakkumdu agar nantinya dalam Penegakan Hukumnya bisa berjalan dengan baik. Rumusan masalah dari Penelitian ini adalah harus mengetahui karateristik tindak pidana pada pemilihan umum dan bagaimana kewenangan Sentra Penagakan Hukum Terpadu pada Badan Pengawas Pemilihan Umum. Metode Pendekatan yang digunakan dalam Penelitian ini adalah Penelitian Hukum Normatif, yaitu penelitian yang mengkaji peraturan hukum, asas-asas hukum dan juga teori/doktrin hukum. penelitian ini juga menggunakan pendekatan perundangundangan dan Pendekatan konseptual yang berkait dengan konsep karakteristik tindak pidana pemilihan umum dan kewenangan lembaga sentra gakkumdu dalam menegakkan hukum pada pelanggaran pemilihan umum. Kesimpulan dari penelitian ini adalah karakteristik tindak pidana pemilihan umum adalah perbuatan yang melawan hukum pada masa Tahapan Pemilu sesuai dengan undang- undang nomor 7 tahun 2017 dan undang-undang nomor 6 tahun 2020, ciri-ciri pemidanaan nya adalah Pelaku yang dapat terjerat Tindak Pidana Pemilihan Umum adalah Peserta Pemilu, Penyelenggara Pemilu dan juga Masyarakat Umum yang berkaitan dengan Pemilu.Tujuannya terdapat pencegahan agar tidak terjadinya tindak pidana Pemilu, dan sebagai alat untuk pencegahan kejahatan sehingga mengandung unsur pencelaan sesuai syarat dan ketentuan yang berlaku.Kewenangan Tindak Pidana Pemilihan Umum adalah Setra Gakkumdu dengan Kewenangan yang bersifat Non Atributif (non orisinil).
\end{abstract}

Kata kunci: pidana; gakkumdu; pemilu

\section{Pendahuluan}

Dalam Perkembangan Hukum di Indonesia terutama pada Masa Pemilihan Umum, masalah hukum pemilu termasuk masalah hukum yang kompleks. Di samping banyaknya kategori masalah, pelaksanaan penanganan masalah hukum pemilu juga melibatkan banyak lembaga/ institusi. Dalam Undang - Undang Nomor 7 Tahun 2017 setidaknya diakui enam jenis masalah hukum pemilu, yaitu : 
pelanggaran kode etik penyelenggara pemilu, pelanggaran administrasi pemilu, sengketa pemilu, tindak pidana pemilu, hukum lainnya (Hamimah, 2018).

Banyaknya jenis masalah hukum pemilu juga linear dengan banyaknya institusi yang terlibat dalam penanganannya. Setidaknya ada sembilan institusi yang terlibat, yaitu: (1) Dewan Kehormatan Penyelenggara Pemilu (DKPP), (2) Badan Pengawas Pemilu (Bawaslu); (3) Komisi Pemilihan Umum (KPU); (4) Kepolisian Negara; (5) Kejaksaan; (6) Pengadilan Tata Usaha Negara dan Pengadilan Tinggi Tata Usaha Negara; (7) Pengadilan Negeri dan Pengadilan Tinggi; (8) Mahkamah Agung; dan Mahkamah Konstitusi (Arifin, 2016). Belum lagi keterlibatan Komisi Penyiaran atau Dewan Pers untuk mengawasi pemberitaan dan iklan kampanye. Sehingga, setidaknya akan ada 10 institusi yang terkait dengan penyelesaian masalah hukum pemilu.

Banyaknya jenis masalah serta banyaknya pihak yang terlibat menunjukkan begitu kompleknya masalah hukum pemilu, atau setidak-tidaknya masalah hukum pemilu didesain dengan demikian kompleks. Jangankan untuk melaksanakan, memahaminya pun butuh energi ekstra agar tidak salah paham yang berakibat fatal dalam pelaksanaannya. Pada gilirannnya, pelaksanaan penegakan hukum

pidana pemilu pun menghadapi berbagai persoalan, baik karena konten aturannya yang tidak terlalu mendukung maupun karena faktor penegak dan budaya hukum.

Maka perlu adanya pembahasan terkait dengan bagaimana bentuk kewenangan sentra penegakkan hukum terpadu dalam menangani tindak pidana pemilihan umum pada badan pengawas pemilihan umum.

\section{Metode Penelitian}

Dalam tulisan ini, Penulis menggunakan metode penelitian hukum yang bersifat Normative, yakni sebuah penelitian yang bahan didapat dari study kepustakaan, selanjutnya mengemukaan problem hukum yang terjadi di masyarakat guna dianalisa menggunakan toeori serta intrepetasi peraturan perundang-undangan yang berlaku, serta beberapa bahan referensi lainnya.

\section{Hasil dan Pembahasan}

\section{Pentingnya Pengaturan Tindak Pidana Pemilu}

Sebelum lebih jauh mengulas arti penting pengaturan tindak pidana pemilu, terlebih dahulu perlu disinggung perihal istilah dan defenisi tindak pidana pemilu (Sudiatmaka \& Mangku, 2019). Secara umum, istilah tindak pidana pemilu merupakan terminologis yang sama atau menjadi bagian dari tindak pidana dalam rezim hukum pidana. Istilah lain untuk "tindak pidana" adalah "perbuatan pidana" atau "delik" yang dalam bahasa Belanda disebut dengan strafbaar feit . Jika dikaitkan dengan pemilu, maka dapat diistilahkan dengan delik pemilu atau tindak pidana pemilu.

Dengan menggunakan istilah delik atau tindak pidana pemilu, ia akan menjadi lebih spesifik, yaitu hanya terkait perbuatan pidana yang terjadi dalam proses penyelenggaraan pemilu. Dalam arti, istilah tindak pidana pemilu diperuntukan bagi 
tindak pidana yang terjadi dalam atau berhubungan dengan pelaksanaan tahapan-tahapan pemilu

Dalam Tindak pidana Pemilihan Umum ("Pemilu") menurut Pasal 1 angka 2 Peraturan Mahkamah Agung Nomor 1 Tahun 2018 tentang Tata Cara Penyelesaian Tindak Pidana Pemilihan dan Pemilihan Umum ("Perma 1/2018") sebagai berikut:

Tindak Pidana Pemilihan Umum yang selanjutnya disebut Tindak Pidana Pemilu adalah tindak pidana pelanggaran dan/atau kejahatan sebagaimana diatur dalam UndangUndang Nomor 7 Tahun 2017 tentang Pemilihan Umum. Defenisi yang sama juga dapat dijumpai dalam Undang-Undang Nomor 1 tahun 2015 sebagaimana diubah dengan Undang-Undang Nomor 8 Tahun 2015 tentang pemilihan Gubernur, Bupati dan Walikota.

Berdasarkan defenisi tersebut, perbuatan/tindakan yang dapat dinilai sebagai tindak pidana pemilu adalah perbuatan yang dikriminalisasi berdasarkan Undang-Undang Pemilu. Sesuai defenisi itu (Afifah, 2014), juga dapat dipahami bahwa tindak pidana pemilu adalah pelanggaran terhadap suatu kewajiban, hal mana pelanggaran tersebut diancam sanksi pidana dalam UU Pemilu.

Lebih jauh, kriminalisasi atas perbuatan tertentu sebagai tindak pidana pemilu dibagi menjadi dua kelompok, yaitu : pelanggaran dan kejahatan. Hanya saja, Undang - Undang Pemilu Legislatif tidak mendefenisikan secara spesifik apa yang dimaksud dengan tindak pidana dalam bentuk pelanggaran dan apa pula cakupan/defenisi tindak pidana kejahatan. Undang - Undang ini hanya mengatur bentuk-bentuk perbuatan yang dikategorikan sebagai pelanggaran dan juga kejahatan yang satu sama lain sulit untuk membedakannya secara pasti (Fahmi, 2016).

Lalu, untuk apa sesungguhnya proses penyelenggaraan pemilu harus ditopang dengan instrumen hukum pidana pemilu? Hal apa yang melatari mengapa instrumen ini menjadi penting? Sebagai bagian dari sistem pengaturan penyelenggaraan pemilu, ketentuan tindak pidana pemilu pada dasarnya untuk menopang terwujudnya pemilu yang jujur dan adil. Dalam konteks itu, arti penting pengaturan tindak pidana pemilu dapat diturun menjadi dua hal penting.

Pertama, norma tindak pidana pemilu ditujukan untuk melindungi peserta pemilu, lembaga penyelenggara dan pemilih dari berbagai tindakan pelanggaran dan kejahatan pemilu yang merugikan. Kedua, norma tindak pidana pemilu ditujukan untuk menegakkan tertib hukum dan masyarakat dalam penyelenggaraan pemilu (Nursyamsi \& Ramadhan, n.d.).

Sehubungan dengan dua tujuan/arti penting pengaturan tindak pidana pemilu tersebut, tentu sangat disadari bahwa pemilu adalah sebuah kontestasi. Di mana, semua pihak tentu akan melakukan langkah apa saja agar dapat memenangkan pemilu, termasuk melakukan pelanggaran. Pelanggaran tersebut dapat saja merugikan peserta pemilu lainnya, merugikan penyelenggara dan juga pemilu.

Kerugian yang dialami peserta bisa dalam bentuk gagalnya yang bersangkutan memeroleh kursi karena adanya kecurangan peserta lain secara langsung ataupun melalui upaya tidak fair melalui kolusi dengan penyelenggara pemilu. Sementara kerugian yang 
dialami penyelenggara bisa saja dalam bentuk terganggungnya proses penyelenggaraan, integritas penyelenggara dan penyelenggaraan pemilu yang berada di bawah tanggung jawabnya. Sedangkan kerugian pemilih bisa terjadi dalam bentuk tidak terjadinya proses konversi suara menjadi kursi sesuai dengan kehendak pemilih melalui proses pemberian suara yang dilakukan pemilih. Agar hak berbagai pihak berkepentingan dalam pemilu dapat terlindungi, maka hukum pidana dijadikan salah satu instrumen memeliharanya. Bagaimanapun, tertib penyelenggaraan pemilu mesti dijaga dengan menggunakan hukum pidana.

Selain itu, sebagai bagian dari hukum pidana, ketentuan pidana pemilu juga ditujukan untuk menegakkan tertib hukum dan masyarakat. Sebagaimana dikemukakan Remmelink, hukum pidana bukan ditujukan pada dirinya sendiri, tetapi ditujukan untuk menegakkan tertib hukum dan melindungi masyarakat hukum, termasuk masuk hukum pemilu.

2. Sistem Peradilan Pidana Pemilu

Sebagai bagian dari rezim hukum pidana, mekanisme peradilan pidana pemilu juga mengikuti sistem peradilan pidana secara umum. Dalam sistem peradilan pidana, terjalin sebuah kerangka jaringan sistem peradilan yang mendayagunakan hukum pidana (hukum pidana materiil, hukum pidana formil dan hukum pelaksanaan pidana) secara terintegrasi. Dalam kerangka itu, semua unsur sub sistem penegakan hukum yang terdiri dari kepolisian, kejaksaan, pengadilan dan lembaga pemasyarakatan terlibat dalam satu jaringan kerja yang saling berkaitan satu sama lain.

Dalam hukum pidana pemilu, sistem kerja demikian juga berlaku. Hanya saja, terdapat sejumlah karakter khusus yang terdapat dalam hukum pidana pemilu. pertama, dari segi hukum materil yang digunakan, tindak pidana pemilu diatur secara khusus dalam UU Pemilu dan UU Pilkada. Sejumlah tindak pidana pemilu bahkan sebelumnya telah ditentukan sebagai tindak pidana umum, seperti melakukan kekerasan atau ancaman kekerasan (Pasal 293 UU Pemilu Legislatif), pemalsuan dokumen (298 UU Pemilu Legislatif), melakukan perbuatan pengrusakan (Pasal 311 UU Pemilu Legislatif). Hanya saja, pengaturan berbagai tindak pidana tersebut dalam UU Pemilu adalah dalam kaitannya dengan pelaksanaan pemilu (Mulyadi, 2019).

Konsekuensinya, tindak pidana tersebut hanya dapat dituntut jika dilakukan dalam konteks pemilu. Dalam arti, berbagai perbuatan yang ditetapkan sebagai tindak pidana pemilu hanya dapat dituntut sesuai UU Pemilu, bukan ketentuan pidana umum. Hal ini sesuai dengan penerapan asas lex specialis derogat legi gerali. Menurut asas ini, semua unsur-unsur suatu rumusan delik terdapat atau ditemukan kembali di dalam peraturan lain, sedangkan peraturan yang disebut kedua (yang khusus) itu disamping semua unsurunsur peraturan pertama (yang umum) memuat pula satu atau beberapa unsur lain (Hamzah, 2012). Dalam kaitan dengan pemilu, unsur lain yang dimaksud adalah tindak pidana tersebut terjadi dalam kaitannya/dalam proses penyelenggaraan pemilu.

Kedua, dari aspek hukum formil, hukum pidana pemilu juga tunduk pada ketentuan yang berlaku dalam Kitab Undang-Undang Hukum Acara Pidana (KUHAP). Di mana, pengadilan negeri dalam memeriksa, mengadili, dan memutus perkara tindak 
pidana pemilu menggunakan KUHAP, kecuali ditentukan lain dalam Pemilu. Frasa "kecuali ditentukan lain dalam Undang-Undang ini" dalam Pasal 262 UU Nomor 8 Tahun 2012 merupakan klausul yang memberi kekhususan tertentu bagi proses pemeriksaan dugaan tindak pidana pemilu.

Salah satu kekhususannya adalah sangat terbatasnya waktu penyidikan, penuntutan dan pemeriksaan oleh pengadilan. Pembatasan waktu dalam memeriksa dan mengadili tindak pidana pemilu sesungguhnya ditujukan agar penanganan tindak pidana pemilu dapat memberikan kepastian hukum bagi tahapan penyelenggaraan pemilu. Selain itu, kekhususan tindak pidana pemilu juga terlihat pada keterbatasan upaya hukum bagi orang yang dinyatakan terbukti melakukan tindak pidana pemilu. Di mana, terhadap putusan pengadilan hanya dapat dilakukan banding dan putusan pengadilan banding (Pengadilan Tinggi) memiliki sifat terakhir dan mengingat serta tidak dapat dilakukan upaya hukum lain. Dengan demikian, upaya kasasi sebagai upaya hukum biasa tidak tersedia dalam pemeriksaan tindak pidana pemilu.

Ketiga, penegakan hukum pidana pemilu tidak saja melibatkan aparatur penegak hukum dalam sistem peradilan pidana biasa, melainkan juga melibatkan institusi penyelenggara pemilu (Setiawan, 2020), dalam hal ini Bawaslu dan jajarannya. Penyidikan dugaan tindak pidana pemilu terlebih dahulu harus dengan adanya laporan/ rekomendasi dari Bawaslu Propinsi dan Panwaslu Kabupaten/kota. Dalam mekanisme tersebut, dugaan pelanggaran pemilu terlebih dahulu harus melalui kajian Bawaslu beserta jajaran. Di mana, apabila hasil kajian pengawas pemilu berkesimpulan adanya dugaan tindak pidana pemilu, maka hasil kajian beserta rekomendasi pengawas pemilu diteruskan kepada penyidik kepolisian.

Oleh karena melibatkan sejumlah institusi dalam penanganan tindak pidana pemilu, maka untuk tujuan menyamakan pemahaman dan pola penanganan tindak pidana pemilu oleh Bawaslu, Kepolisian dan Kejaksaan, diatur dan dibentuklah sebuah sentra penegakan hukum terpadu (Sentra Gakumdu). Di mana, institusi ini berkedudukan sebagai tempat untuk menyamakan pandangan antar institusi yang terlibat dalam menangani tindak pidana pemilu (Yeni, 2020).

Hanya saja, dalam pengaturan teknis dan praktiknya, Gakkumdu justru ditempatkan sebagai institusi yang bertugas menyelenggarakan penanganan tindak pidana pemilu secara terpadu. Pada saat yang sama, juga memberi penilaian apakah bukti-bukti dugaan tindak yang diserahkan Bawaslu beserta jajaran telah terpenuhi atau setidak. Dalam konteks itu, dalam keadaan tertentu, penyidik kepolisian justru hanya memosisikan diri sebagai pihak yang menerima bersih laporan tanpa melakukan penyidikan lagi. Padahal, sesuai UU Pemilu, penyidik kepolisian yang semestinya melakukan penyidikan atas telah terjadinya dugaan tindak pidana pemilu.

Keempat, pemeriksaan perkara tindak pidana ditangani oleh majelis khusus yang dibentuk pada pengadilan negeri maupun pengadilan tinggi.23 Di mana, hakim khusus perkara pidana pemilu mesti memiliki syarat dan kualifikasi tertentu yang pengangkatannya ditetapkan berdasarkan Keputusan Kedua Mahkamah Agung Republik Indonesia. 24 
Setidaknya empat hal itulah yang menunjukan kekhususan sistem peradilan pidana pemilu yang diatur dalam UU Nomor 8 Tahun 2012. Selanjutnya akan digambarkan sistem peradilan pidana pemilu sebagaimana diatur dalam UU tersebut. Hanya saja, karena sistem peradilan pidana pemilu juga melibatkan Bawaslu dan jajaran, terlebih dahulu akan digambarkan proses penanganan pelanggaran pemilu oleh pengawas pemilu. Sebab, penanganan perkara pelanggaran pemilu (termasuk pidana) oleh Bawaslu dan jajaran merupakan pintu awal untuk seluruh proses penegakan hukum pemilu yang lainnya. Oleh karena itu, secara berturut-turut akan ditampilkan bagan sistem penyelesaian pelanggaran pemilu oleh Bawaslu dan bagan sistem penanganan tindak pidana pemilu yang melibatkan Bawaslu, kepolisian, kejaksaan dan pengadilan.

\section{Alur Penanganan Pelanggaran Pemilu}

(Berdasarkan Perbawaslu Nomor 7 Tahun 2018)

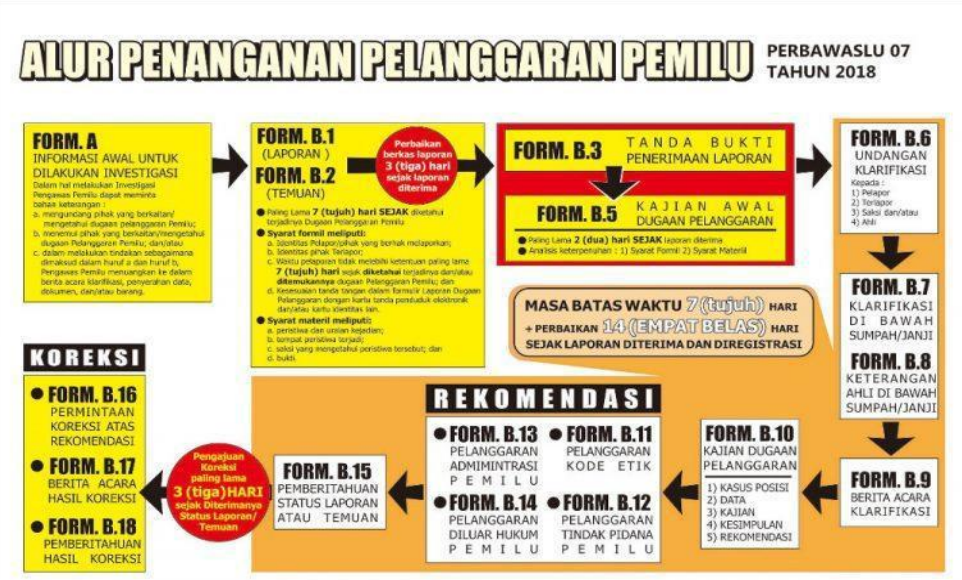

Alur Penanganan Tindak Pidana Pemilu

(Berdasarkan Perbawaslu nomor 09 Tahun 2018)

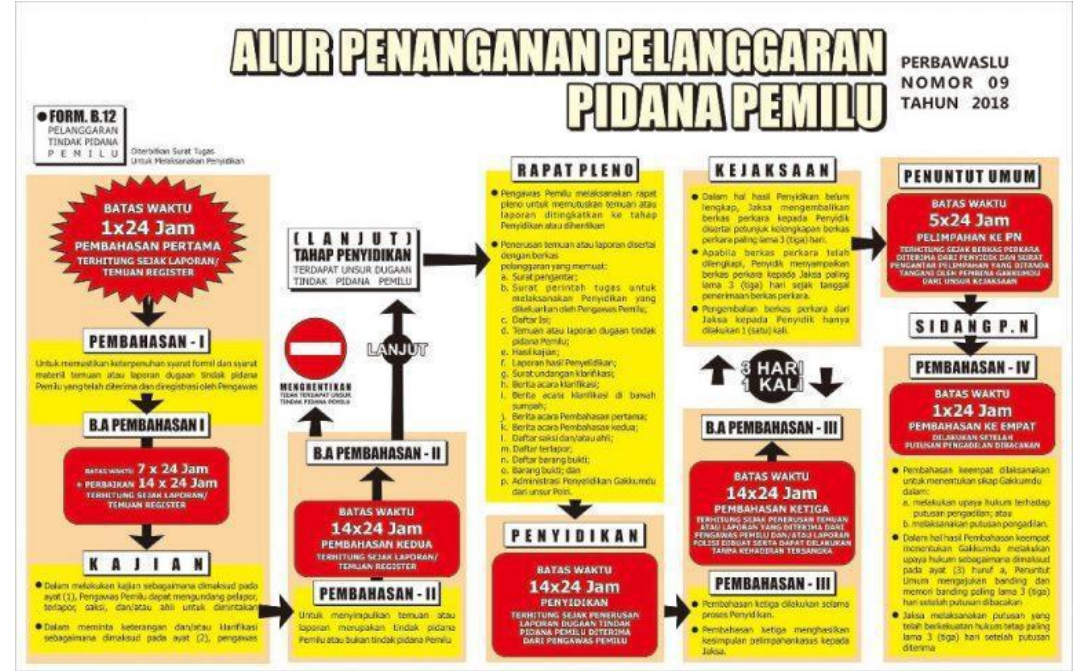

Alur penanganan tindak pidana dalam sistem peradilan pidana pemilu sebagaimana diuraikan di atas menunjukkan birokrasi penanganan yang tidak sederhana. Sistem penanganan tindak pidana pemilu jauh lebih rumit dibandingkan tindak pidana 
biasa yang hanya melibatkan polisi, jaksa dan pengadilan. Sementara tindak pidana pemilu juga melibatkan pengawas pemilu. Sehingga, kondisi inipun dinilai sebagai salah satu alasan kenapa penanganan tindak pidana pemilu menjadi tidak efektif (Sulistyoningsih, 2015).

Dengan waktu penanganan tindak pidana pemilu yang amat singkat, birokrasi penanganan tindak pidana pemilu mesti didesain lebih sederhana. Di mana, keterlibatan polisi dan jaksa lagi ditempatkan secara terpisah dari proses pengawasan pemilu yang dilakukan pengawas pemilu. Dalam konteks ini, polisi dan jaksa harus didesain berada dalam satu kesatuan lembaga pengawas pemilu dalam menegakkan hukum pidana pemilu. Dalam konteks ini, mengubah desain kelembagaan pengawas pemilu dengan memasukkan unsur polisi dan jaksa secara ex officio merupakan salah satu cara untuk memotong panjangnya rangkaian birokrasi penangan perkara tindak pidana pemilu. Dengan cara itu, semua tindakan penyelidikan, penyidikan dan penuntutan tindak pidana pemilu akan berada di bawah satu komanda. Sehingga penegakan hukum pidana pemilu dalam waktu yang sangat singkat tentunya akan berjalan lebih baik

3. Pembuktian Tindak Pidana Pemilu

Undang-Undang Nomor 7 Tahun 2017 tidak mengatur secara khusus ikhwal pembuktian dalam perkara tindak pidana pemilu. Dalam arti, tidak terdapat ketentuan yang memberikan karakter tersendiri dalam pembuktian tindak pidana pemilu. Ketiadaan pengaturan pembuktian tindak pidana pemilu berkonsekuensi terhadap tunduknya rezim pembuktian tindak pidana pemilu pada sistem pembuktian dalam KUHAP. Hal itu didasarkan pada ketentuan Pasal 481 ayat (1) yang menyatakan, Pengadilan negeri dalam memeriksa, mengadili, dan memutus perkara tindak pidana Pemilu menggunakan Kitab Undang-Undang Hukum Acara Pidana, kecuali ditentukan lain dalam Undang-Undang ini. Ketentuan tersebut mengisyaratkan bahwa pembuktian tindak pidana pemilu sepenuhnya mengikuti apa yang diatur dalam KUHAP.

Dengan karakter khusus yang dimiliki tindak pidana pemilu, seperti singkatnya waktu penanganan, sesungguhnya membutuhkan adanya ketentuan terkait pembuktian yang lebih spesifik selain yang diatur dalam KUHAP. Jika hanya mengacu pada KUHAP, penanganan tindak pidana pemilu akan jauh dari efektif. Apalagi untuk tujuan mengawal integritas pemilu yang jujur dan adil.

Jika dibandingkan dengan penanganan tindak pidana korupsi, salah satu faktor yang mendukung efektifitas penanganan tindak pidana korupsi adalah tersedianya ruang pembuktikan lebih luas dibanding apa yang termuat dalam KUHAP. Salah satunya, perluasan definisi bukti petunjuk sebagaimana diatur dalam Pasal 188 ayat (2) KUHAP. Dalam Pasal 26 A Undang-Undang Nomor 20 Tahun 2001 tentang Perubahan UndangUndang Nomor 31 Tahun 1999 tentang Tindak Pidana Korupsi diatur sebagai berikut :

Alat bukti yang sah dalam bentuk petunjuk sebagaimana dimaksud dalam Pasal 188 ayat (2) Undang-undang Nomor 8 Tahun 1981 tentang Hukum Acara Pidana, khusus untuk tindak pidana korupsi juga dapat diperoleh dari:

1. Alat bukti lain yang berupa informasi yang diucapkan, dikirim, diterima, atau disimpan secara elektronik dengan alat optik atau yang serupa dengan itu; dan 
2. Dokumen, yakni setiap rekaman data atau informasi yang dapat dilihat, dibaca, dan atau didengar yang dapat dikeluarkan dengan atau tanpa bantuan suatu sarana, baik yang tertuang di atas kertas, benda fisik apapun selain kertas, maupun yang terekam secara elektronik, yang berupa tulisan, suara, gambar, peta, rancangan, foto, huruf, tanda, angka, atau perforasi yang memiliki makna.

Ketentuan UU Pemberantasan Tindak Pidana Korupsi di atas memberi kesempatan cukup luas bagi penyidik untuk membuktikan dugaan tindak pidana korupsi secara lebih mudah. Sebab, penyidik tidak saja terbatas pada cara memperoleh alat bukti yang diatur dalam KUHAP, melainkan lebih luas dari itu.

Jika hal yang sama diterapkan dalam penanganan tindak pidana pemilu, tentunya pembuktian tindak pidana pemilu akan jauh lebih mudah. Sebab, penyidik memiliki sumber bukti yang lebih luas dari sekedar ketentuan KUHAP yang dapat dikatakan sangat terbatas. Sehingga, sebuah dugaan tindak pidana pemilu tidak dengan mudah lolos karena alasan tidak cukup bukti untuk membawanya ke proses pengadilan (Soerodibroto, 1919).

Apalagi tindak pidana pemilu sangat mudah diselundupkan ke dalam berbagai aktifitas lainnya. Dengan berbagai cara, pelaku tindak pidana pemilu justru mudah untuk lepas dari jeratan hukum karena bukti-bukti terjadinya tindak pidana pemilu sangat sulit untuk ditemukan.

4. Problem Penegakan Hukum Pidana Pemilu

Problem penegakan hukum pidana pemilu setidaknya dapat disigi dengan melihat masing-masing komponen dalam sistem hukum yang secara langsung berpengaruh terhadap penegakan hukum. Lawrence M. Friedman menilai, berhasil atau tidaknya hukum ditegakkan tergantung pada tiga komponen sistem hukum. Pertama, substansi hukum (legal substance). Substansi hukum adalah aturan, norma, dan pola prilaku nyata manusia yang berada dalam sistem itu.

Kedua, struktur hukum (legal structure) atau struktur sistem hukum. Friedman menyebutnya sebagai kerangka atau rangka atau bagian yang tetap bertahan atau bagian yang memberi semacam bentuk dan batasan terhadap keseluruhan. Keberadaan struktur hukum sangat penting, karena betapapun bagusnya norma hukum, namun jika tidak ditopang aparat penegak hukum yang baik, penegakan hukum dan keadilan hanya sia-sia. Ketiga, budaya hukum (legal culture). Kultur hukum adalah opini-opini, kepercayaan-kepercayaan (keyakinan-keyakinan), kebiasaan-kebisaaan, cara berfikir, dan cara bertindak, baik dari para penegak hukum maupun dari warga masyarakat tentang hukum dan berbagai fenomena yang berkaitan dengan hukum (Ali, 2009).

Berangkat dari tiga indikator tersebut, belum efektifnya penegakan hukum pidana pemilu juga tidak dapat dilepaskan dari masalah yang terdapat dalam peraturan perundang-undangan pemilu, khususnya terkait tindak pidana pemilu; masalah profesionalisme aparat penegakan hukum yang terdiri dari pengawas pemilu, kepolisian, kejaksanaan dan hakim pada pengadilan Negeri dan Pengadilan Tinggi; dan budaya hukum penyelenggaraan pemilu yang jauh dari kondisi sehat.

Pada taraf norma, peraturan perundang-undangan sebagaimana diulas pada bagian sebelumnya belum cukup jelas dan lengkap mengatur hukum materil maupun 
hukum formil. Bahkan hukum formil yang ada tidak cukup memadai untuk menegakkan hukum pidana pemilu secara efektif. Sementara pada level struktur, penegak hukum dihadapkan pada persoalan masih belum memadainya pemahaman aparatur terhadap jenis tindak pidana pemilu; belum profesional dan masih terjadinya "tolak-menolak" yang berujung pada kebuntuan dalam menangani perkara pidana pemilu. Sedangkan pada ranah budaya hukum, pihak-pihak berkepentingan, terutama peserta pemilu masih berkecenderungan untuk "mengakali" aturan yang ada sehingga dapat berkelit dari tuntutan hukum. Masyarakat politik bukannya membangun kesadaran akan perlunya mengikuti pemilu sesuai aturan-aturan yang ada, melainkan justru membangun sikap culas atas aturan yang ada (Santoso, 2017).

Tiga persoalan penegakan hukum pidana pemilu tersebut berkelindan sedemikian rupa sehingga penegakan hukum pemilu benar-benar lumpuh (sekedar tidak mengatakan mati suri). Akibatnya, perkara-perkara dugaan tindak pidana pemilu pun tidak tertangani dengan baik.

\section{Kesimpulan}

Sistem penanganan tindak pidana pemilu masih membutuhkan pembenahan agar dapat diterapkan dengan baik dan efektif untuk menjadi salah satu instrumen mewujudkan pemilu yang jujur dan adil. Perbaikan sistem penanganan meliputi perbaikan regulasi; penguatan kapasitas dan profesionalisme penegak hukum pemilu; dan peningkatan kesadaran hukum seluruh pemangku kepentingan pemilu. Tanpa melakukan itu, sistem penanganan tindak pidana pemilu akan selalu jalan di tempat dan tidak akan berhasil guna dalam menopang perwujudan pemilu yang jujur dan adil. 


\section{Bibliografi}

Afifah, Wiwik. (2014). Tindak Pidana Pemilu Legislatif di Indonesia. Mimbar Keadilan, 240075.

Ali, Achmad. (2009). Menguak Teori Hukum (Legal Theory) dan Teori Peradilan (Judicialprudence). Jakarta: Kencana Prenada Media Grup.

Arifin, Firmansyah. (2016). Penegakan Hukum Pemilu: Tinjauan Atas Putusan Pengadilan Tindak Pidana Pemilu 2014. Jurnal Hukum PRIORIS, 4(3), 348-364.

Fahmi, Khairul. (2016). Sistem Penanganan Tindak Pidana Pemilu. Jurnal Konstitusi, 12(2), 264-283.

Hamimah, Siti. (2018). Memperkuat Peran dan Fungsi BAWASLU dalam Pengawasan dan Penegakan Hukum PEMILU. Seminar Nasional Hukum Universitas Negeri Semarang, 4(3), 803-828.

Hamzah, Andi. (2012). Asas-asas hukum pidana di Indonesia \& perkembangannya. Sofmedia.

Mulyadi, Dudung. (2019). Analisis Penerapan Bentuk-Bentuk Tindak Pidana Pemilu. Jurnal Ilmiah Galuh Justisi, 7(1), 14-28.

Nursyamsi, Fajri, \& Ramadhan, Muhammad Nur. (n.d.). PELINDUNGAN HAK PILIH PENYANDANG DISABILITAS MENTAL DALAM PENDEKATAN RANGKAIAN PROSES PASCA PUTUSAN MAHKAMAH KONSTITUSI NOMOR 135/PUU-VIII/2015 PERSONS WITH MENTAL DISABILITIES RIGHTS TO VOTE. JURNAL, 17.

Santoso, Topo. (2017). Pengaturan tindak pidana pemilu di empat negara asia tenggara. Jurnal Hukum \& Pembangunan, 34(2), 129-142.

Setiawan, Andi. (2020). JEJARING KELEMBAGAAN BAWASLU DALAM PENANGANAN PELANGGARAN PEMILIHAN UMUM SERENTAK. Jurnal Academia Praja, 3(02), 322-340.

Soerodibroto, R. Soenarto. (1919). KUHP dan KUHAP: Dilengkapi Yusrisprudensi Mahkamah Agung dan Hoge Raad. -.

Sudiatmaka, Ketut, \& Mangku, Dewa Gede Sudika. (2019). Penanganan dan Penegakan Hukum Terkait Pemilihan Kepala Daerah Secara Langsung di Kabupaten Buleleng. Jurnal Media Komunikasi Pendidikan Pancasila Dan Kewarganegaraan, 1(1), 2535 .

Sulistyoningsih, Dewi Permatasari. (2015). Pertanggungjawaban Pidana Dalam Tindak Pidana Pemilu (Studi Terhadap Pelanggaran Pemilu Di Indonesia). Mimbar Keadilan, 278186. 
Penanganan Tindak Pidana Pemilu Dalam Sentra Penegakkan Hukum Terpadu

(Gakkumdu)

Yeni, Yeni. (2020). Peran Sentra Penegakan Hukum Terpadu (Gakkumdu) Dalam Penindakan Tindak Pidana Pemilu Pada Pemilihan Anggota Dewan Perwakilan Rakyat Daerah Kabupaten Solok Tahun 2019. Abstract of Undergraduate Research, Faculty of Law, Bung Hatta University, 11(1). 